\title{
POLA KONSENTRASI SPASIAL INDUSTRI KECIL MENENGAH DI PROVINSI NUSA TENGGARA BARAT
}

\section{CHANDRADITYA BAGASKARA ${ }^{1)}$, PUTU KARISMAWAN ${ }^{2),}$ FIRMANSYAH $^{3)}$}

${ }^{1}$ Alumni FEB Universitas Mataram, ${ }^{2,3}$ Dosen FEB Universitas Mataram

\author{
e-mail: putukarismawan@gmail.com
}

\begin{abstract}
ABSTRAK
Teori lokasi memberi kerangka analisis yang sistematis mengenai pemilihan lokasi kegiatan ekonomi dan sosial. Pemilihan lokasi yang tepat dapat memberikan penghematan cukup besar dalam ongkos angkut dan biaya produksi sehingga mendorong terjadinya efisiensi, baik dalam bidang produksi maupun pemasaran. Efisiensi berdampak pada meningkatnya keuntungan perusahaan dan bermuara pada terkonsentrasinya kegiatan ekonomi. Ada banyak faktor yang mempengaruhi konsentrasi kegiatan ekonomi, antara lain faktor upah, ketersediaan tenaga kerja dan produktivitas. Hasil analisis menggunakan Rasio Konsentrasi dapat diketahui industri kecil menengah terkonsentrasi di Kota Mataram dan Kabupaten Lombok Tengah. Sedangkan hasil dari Indeks Konsentrasi dapat diketahui tenaga kerja terkonsentrasi di Kabupaten Sumbawa, Kabupaten Lombok Utara, Kabupaten Lombok Tengah, Kota Bima, Kabupaten Bima dan Kabupaten Lombok Barat. Atas dasar itu dapat disimpulkan bahwa pola konsentrasi spasial industri kecil menengah tidak merata antar kabupaten/kota di Provinsi Nusa Tenggara Barat. Dari hasil Regresi Data Panel dengan metode Random Effect Model disimpulkan bahwa konsentrasi spasial industri kecil menengah secara signifikan dipengaruhi oleh variabel tenaga kerja dan nilai produktivitas, sedangkan upah tidak berpengaruh signifikan terhadap konsentrasi spasial industri kecil menengah di Provinsi Nusa Tenggara Barat.
\end{abstract}

Kata kunci : Konsentrasi Spasial, Industri Kecil Menengah, Tenaga Kerja.

\section{ABSTACT}

Location Theory gives systematic analysis framework of selecting location of economic adn social activities. Chosing of the right location thrifts reduce the transportation and production cost that drives efficient in production and marketing. The impact of efficiency is the higest profit and concentration of economic activities. There are many factor afecting the concentration of economic activities, such as wages, man power sources and productivity. Based on Concentration Ratio analysis that Small-medium industries cosentrated in Mataram City and Central Lombok distric. Based on concentration Index of Man power shows that the concentration of man power are in Sumbawa district, North Lombok, Central Lombok, Bima City, Bima district and West Lombok district. Based on those result that concentration spatial of SmallMedium Industries in each district of West Nusa Tenggara are not equal. Based on Regresioan analysis with Randomeffect Model that concentration of small-medium industries in West Nusa Tenggara siginificanly corelated with amount of man power and productivity, neither than wages.

Keywords: spatial concentration, smal-medium industries, man power.

\section{PENDAHULUAN}

Provinsi NTB merupakan daerah dengan pertumbuhan ekonomi yang tinggi dan memiliki industri manufaktur dengan skala usaha industri kecil menengah yang cukup besar. Permintaan hasil industri manufaktur yang terus bertambah didorong oleh pertumbuhan penduduk, peningkatan pendapatan, kegiatan ekonomi dan migrasi dari wilayah lain ke wilayah Provinsi NTB (urbanization economies).

Peran sektor sekunder industri pengolahan selama tahun 2012-2016 mengalami peningkatan yang cukup signifikan. Kontribusi industri pengolahan terhadap perekonomian Provinsi NTB sebesar 4,80 persen dengan laju pertumbuhan pada tahun 2016 sebesar 5,32 persen. Pertumbuhan PDRB dari tahun ke tahun dari sektor industri yang terus meningkat ini menunjukkan bahwa sektor industri di Provinsi NTB sangat 
berpotensi untuk terus dikembangkan. Sedangkan untuk lapangan usaha yang mencatatkan laju pertumbuhan terbesar adalah industri makanan dan minuman yaitu sebesar 9,98 persen, kemudian diikuti oleh industri kayu, barang dari kayu dan gabus dan barang anyaman dari bambu, rotan dan sejenisnya, dan industri furnitur yaitu sebesar 6,90 persen dan 6,15 persen (BPS, 2016).

Aktivitas industri yang ada di Provinsi NTB pada umumnya merupakan industri kecil menengah. Penciptaan nilai tambah terbesar pada lapangan usaha industri ini berasal dari aktivitas industri makanan dan minuman yaitu sekitar 51 persen dan aktivitas pengolahan tembakau yang berupa pengeringan daun tembakau sekitar 26 persen. Memperhatikan tingginya peranan lapangan usaha pertanian dikaitkan dengan peranan lapangan usaha industri, mengindikasikan bahwa aktivitas industri khususnya yang mengolah hasilhasil pertanian harus dioptimalkan. Oleh karena itu, untuk meningkatkan peranan lapangan usaha industri dapat dilakukan dengan mengoptimalkan aktivitas dan kinerja industri terutama industri kecil menengah.

Sektor industri kecil menengah Provinsi NTB mengalami perkembangan setiap tahunnya baik dalam jumlah perusahaan (unit usaha), tenaga kerja, nilai investasi dan nilai produksi pada industri tersebut. Pada tahun 2012 banyaknya industri kecil menengah yaitu 82.073 unit usaha dan menyerap tenaga kerja sebanyak 255.562 orang, sedangkan pada tahun 2016 jumlah industri kecil menengah mengalami peningkatan yaitu 85.274 unit usaha dan berhasil menyerap tenaga kerja sebanyak 260.220 orang. Hal itu menunjukkan kenaikan rata-rata jumlah industri kecil menengah dan tenaga kerja masing-masing sebesar 1,01 persen dan 0,62 persen.

Nilai investasi pada sektor industri kecil menengah di Provinsi NTB pada tahun 2012 adalah sebesar Rp. 423,090 milyar dengan nilai produksinya sebesar Rp. 2.146,647 milyar, sedangkan pada tahun 2016 nilai investasi industri kecil menengah yaitu Rp. 773,603 milyar yang naik dari tahun 2012 sebesar 17,72 persen dengan nilai produksi sebesar Rp. 3.665,953 milyar yang juga menunjukkan kenaikan sebesar 40,63 persen dari tahun 2012.

Dalam perkembangannya, pertumbuhan sektor industri kecil menengah di Provinsi NTB mengalami ketimpangan secara wilayah atau ketimpangan spasial. Hal ini dapat dipahami, karena aktivitas ekonomi di suatu wilayah akan sangat dipengaruhi oleh kondisi geografis dari wilayah tersebut. Industri cenderung beraglomerasi di daerah-daerah dimana potensi dan kemampuan daerah tersebut memenuhi kebutuhan mereka, dan mereka mendapat manfaat akibat lokasi perusahaan yang saling berdekatan. Teori lokasi tradisional berpendapat bahwa pengelompokan industri muncul terutama akibat minimisasi biaya transport atau biaya produksi (Mudrajad, 2002: 2).

Industri kecil menengah juga berperan penting dalam penyerapan tenaga kerja. Penyerapan tenaga kerja merupakan jumlah tertentu dari tenaga kerja yang digunakan (bekerja) dalam suatu unit usaha tertentu. NTB merupakan provinsi yang mengalami peningkatan penyerapan tenaga kerja IKM yang cukup besar, hal ini terlihat dari jenis industri yang menyerap tenaga kerja lebih tinggi adalah pada industri kecil menengah dibandingkan dengan industri besar yaitu pada tahun 2014-2016 industi besar sebanyak 5.542 orang - 9.935 orang. Sedangkan pada industri kecil menengah pada tahun 2014-2016 mampu menyerap tenaga kerja sebanyak 260.016 orang -260.220 orang. Pertumbuhan ekonomi dan penyerapan tenaga kerja akan lebih optimal jika adanya pengelompokan aktivitas ekonomi secara spasial.

Konsentrasi spasial merupakan pengelompokan setiap industri dan aktivitas ekonomi secara spasial, dimana industri tersebut berlokasi pada suatu wilayah tertentu. Krugman menyatakan bahwa dalam konsentrasi aktivitas ekonomi secara spasial, ada tiga hal yang saling terkait yaitu interaksi antara skala ekonomi, biaya transportasi dan permintaan. Untuk mendapatkan dan meningkatkan kekuatan skala ekonomis, perusahaan-perusahaan cenderung berkonsentrasi secara spasial dan melayani seluruh pasar dari suatu lokasi. Sedangkan untuk meminimalisasi biaya transportasi, perusahaan cenderung berlokasi pada wilayah yang memiliki permintaan lokal yang besar, akan tetapi permintaan lokal yang besar cenderung berlokasi di sekitar terkonsentrasinya aktivitas ekonomi seperti kawasan industri maupun perkotaan (Mudrajad, 2002).

Konsentrasi spasial didorong oleh ketersediaan tenaga kerja yang terspesialisasi dimana berkumpulnya perusahaan pada suatu lokasi akan mendorong berkumpulnya tenaga kerja, sehingga menguntungkan perusahaan dan tenaga kerja. Selain itu, berkumpulnya perusahaan atau industri yang saling terkait akan dapat meningkatkan efisiensi dalam pemenuhan kebutuhan input yang terspesialisasi yang lebih baik dan lebih murah, jarak yang tereduksi dengan adanya konsentrasi spasial akan akan memperlancar arus informasi dan pengetahuan (knowledge spillover) pada lokasi tersebut (Mudrajad, 2002).

Konsentrasi spasial menunjukkan share suatu wilayah dan distribusi lokasi dari suatu industri. Apabila suatu distribusi spasial suatu industri tidak merata dan ada wilayah yang mendominasi berlokasinya industri, maka menunjukkan bahwa industri terkonsentrasi sacara spasial di wilayah tersebut. Konsentrasi spasial menunjukkan bahwa industri tidak berlokasi secara merata pada seluruh wilayah, akan tetapi mengelompok secara berdekatan pada bagian tertentu pada wilayah tersebut (Aiginger dan Hansberg, 2003). 
Formulasi teori lokasi dan analisa spasial dilakukan dengan memperhatikan faktor-faktor utama yang menentukan pemilihan lokasi kegiatan ekonomi, baik pertanian, industri dan jasa. Disamping itu, pada umumnya faktor yang dijadikan dasar perumusan teori adalah yang dapat diukur agar menjadi lebih kongkrit dan operasional. Menurut Sjafrizal (2008), terdapat 6 faktor ekonomi utama yang mempengaruhi pemilihan lokasi kegiatan ekonomi, yaitu :ongkos angkut, perbedaan upah antar wilayah, keuntungan aglomerasi, konsentrasi permintaan, kompetisi antar wilayah, harga dan sewa tanah.

\section{Rumusan Masalah}

Berdasarkan uraian latar belakang di atas, maka permasalahan dalam penelitian ini yaitu "Bagaimana pola konsentrasi spasial pembangunan ekonomi dilihat dari konsentrasi industri kecil menengah dan tenaga kerja antar kabupaten/kota di Provinsi Nusa Tenggara Barat?

\section{Tujuan dan Manfaan Penelitian}

Adapun tujuan penelitian ini yaitu untuk mendeskripsikan pola konsentrasi spasial pembangunan ekonomi dilihat dari konsentrasi industri kecil menengah dan tenaga kerja antar kabupaten/kota di Provinsi Nusa Tenggara Barat. Sedangkan manfaan dari hasil penelitian ini dapat dijadikan refrensi atau rujukan dalam mengambil kebijakan pembangunan prasarana dan infrastruktur yang mempunyai peranan cukup tinggi dalam menciptakan pertumbuhan ekonomi antar daerah.

\section{METODE PENELITIAN}

\section{Analisis Rasio Konsentrasi}

Rasio konsentrasi (Concentration Ratio) adalah alat ukur untuk menghitung konsentrasi spasial industri kecil menengah antar kabupaten/kota di Provinsi NTB. Rasio konsentrasi merupakan share pencapaian $\mathrm{N}$ perusahaan terbesar dalam suatu industri terhadap total pencapaian industri. Rasio konsentrasi untuk 4 perusahaan terbesar dapat dihitung, secara sederhana, dengan menjumlahkan pangsa pasar 4 perusahaan tersebut (Gwin, 2000 dalam Arsyad dan Kusuma, 2014) dengan rumus sebagai berikut :

$$
\begin{aligned}
& \text { CR4 }=\sum_{\mathrm{i}} \mathrm{P}_{\mathrm{i}}^{\mathrm{j}} \\
& \mathrm{P}_{\mathrm{i}}^{\mathrm{j}}=\frac{\text { Nilai Output Industri j di Kabupaten/Kota i }}{\text { Total Nilai Output Industri Provinsi }}
\end{aligned}
$$

Keterangan :

CR4 = Konsentrasi Spasial 4 Industri dengan nilai output terbesar

$\mathrm{P}_{\mathrm{i}}^{\mathrm{j}} \quad=$ Proporsi Output

$\mathrm{j} \quad=\mathrm{A}, \mathrm{B}, \mathrm{C}, \mathrm{D}$

$\mathrm{A} \quad=$ Industri Pangan

$\mathrm{B} \quad=$ Industri Sandang

$\mathrm{C}=$ Industri Kimia dan Bahan Bangunan

$\mathrm{D} \quad=$ Industri Logam dan Elektronika

$\mathrm{i} \quad=10 \mathrm{Kabupaten} /$ Kota

Nilai CR4 dapat memberikan gambaran tentang peran 4 perusahaan terbesar yang ada dalam industri. Rasio konsentrasi berkisar antara nol hingga satu dan bisa dinyatakan dalam persentase. Nilai konsentrasi yang semakin mendekati 0 mengindikasikan pangsa pasar dan peran sejumlah perusahaan terbesar yang semakin kecil dalam industrinya. Sebaliknya, angka rasio konsentrasi yang semakin mendekati 1 mengindikasikan pangsa pasar dan peran sejumlah perusahaan terbesar yang semakin besar dalam industrinya.

\section{Analisis Indeks Konsentrasi}

Indeks konsentrasi mengacu pada rasio tenaga kerja dibandingkan dengan jumlah penduduk. Indeks konsentrasi adalah salah satu alat ukur untuk menguji pola konsentrasi geografis (LPEM, UI, 2003) dengan rumus sebagai berikut :

Dimana :

$$
\mathrm{CI}=\left\{\left(\mathrm{Ep}_{\mathrm{i}} / \mathrm{Pp} \mathrm{i}\right) /(\mathrm{En} / \mathrm{Pn})\right\}
$$

$\mathrm{CI} \quad=$ Indeks Konsentrasi

$\mathrm{Ep}_{\mathrm{i}} \quad=$ Tenaga Kerja Kabupaten/Kota i di Provinsi Nusa Tenggara Barat

En $\quad=$ Tenaga Kerja Provinsi Nusa Tenggara Barat

$\mathrm{Pp}_{\mathrm{i}} \quad=$ Jumlah Penduduk Kabupaten/Kota i di Provinsi Nusa Tenggara Barat

$\mathrm{Pn} \quad=$ Jumlah Penduduk Provinsi Nusa Tenggara Barat

$\mathrm{i}=10 \mathrm{Kabupaten} /$ Kota 
Apabila hasil indeks konsentrasi (CI) :

- CI>1 : Kabupaten/kota yang bersangkutan memiliki peran lebih besar daripada peran Provinsi NTB dalam penyerapan tenaga kerja. Berarti terjadi konsentrasi tenaga kerja dalam perekonomian daerah tersebut,

- $\mathrm{CI}=1$ : Kabupaten/kota yang bersangkutan memiliki peran sama dengan peran Provinsi NTB dalam penyerapan tenaga kerja,

- $\mathrm{CI}<1$ : Kabupaten/kota yang bersangkutan memiliki peran lebih kecil daripada peran Provinsi NTB dalam penyerapan tenaga kerja. Berarti tidak terjadi konsentrasi tenaga kerja dalam perekonomian daerah tersebut.

\section{Analisis Regresi Data Panel}

Model data panel yang digunakan adalah pendekatan model efek acak (Random Effect). Dalam model efek acak, parameter-parameter yang berbeda antar daerah maupun antar waktu dimasukkan ke dalam error.

Model tersebut menyebutkan bahwa konsentrasi spasial adalah fungsi dari jumlah tenaga kerja, upah dan nilai produktivitas dapat ditulis sebagai berikut :

$$
\mathrm{CR} 4=\mathrm{f}(\mathrm{TK}, \mathrm{U}, \mathrm{NP}) \text {. }
$$

Dari model ekonomi diatas kemudian ditransformasikan ke spesifikasi model ekonometrika sebagai berikut :

$\mathrm{CR} 4_{\text {it }}=\beta_{0}+\beta_{1} \mathrm{TK}_{\mathrm{it}}+\beta_{2} \mathrm{U}_{\mathrm{it}}+\beta_{3} \mathrm{NP}_{\mathrm{it}}+\varepsilon_{\mathrm{it}}$

Adanya perbedaan satuan dan besaran variabel bebas dalam persamaan menyebabkan persamaan regresi harus ditransformasi dalam bentuk persamaan model logaritma. Dalam model penelitian ini logaritma yang digunakan adalah dalam bentuk logaritma-linier (log) dimana semua data variabel baik variabel terikat maupun variabel bebas dilinierisasikan menjadi bentuk logaritma-linier sehingga menghasilkan persamaan sebagai berikut :

$$
\log C R 4_{i t}=\log \beta_{0}+\beta_{1} \log \mathrm{TK}_{\mathrm{it}}+\beta_{2} \log \mathrm{U}_{\mathrm{it}}+\beta_{3} \log \mathrm{NP}_{\mathrm{it}}+\varepsilon_{\mathrm{it}} \ldots \ldots . .(3.3)
$$

Keterangan :

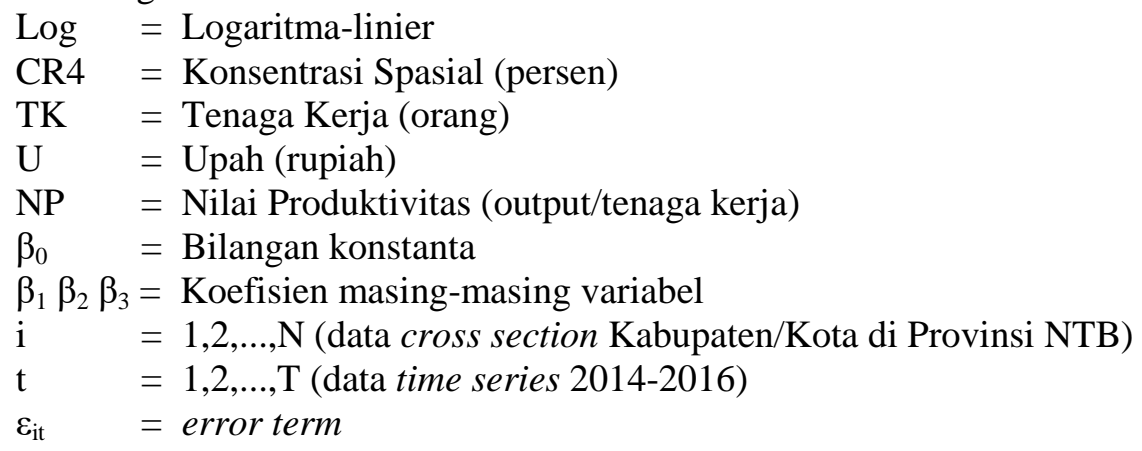

\section{HASIL DAN PEMBAHASAN}

\section{Gambaran Perindustrian Provinsi Nusa Tenggara Barat}

Pembangunan di sektor industri merupakan prioritas utama pembangunan ekonomi tanpa mengabaikan pembangunan di sektor lainnya. Industri merupakan perusahaan atau usaha yang membentuk satu kesatuan usaha dalam melakukan kegiatan ekonomi, bertujuan menghasilkan barang atau jasa terletak pada suatu lokasi tertentu dan memiliki catatan administrasi tersendiri mengenai produksi dan struktur biaya serta ada seseorang atau lebih yang bertanggung jawab atas resiko usaha tersebut (Martin, 1994: 4).

Menurut BPS sektor industri manufaktur dibedakan menjadi empat bagian yaitu, industri besar, industri menengah, industri kecil dan industri mikro atau industri rumah tangga. Sektor industri yang diharapkan dapat menopang sektor pertanian di Provinsi NTB belum memberikan sharing yang cukup dalam perekonomian NTB, karena peranannya hanya baru sekitar 5 persen. Kecilnya sharing sektor industri karena mayoritas industri yang ada di NTB adalah industri kecil dan kerajinan rumah tangga. Penciptaan nilai tambah terbesar pada lapangan usaha industri berasal dari aktivitas industri makanan dan minuman yaitu sekitar 51 persen dan aktivitas pengolahan tembakau yang berupa pengeringan daun tembakau sekitar 26 persen.

Secara keseluruhan, laju pertumbuhan kategori industri pengolahan pada tahun 2016 adalah sebesar 5,32 persen, sedangkan lapangan usaha yang mencatatkan laju pertumbuhan terbesar adalah industri makanan dan minuman yaitu sebesar 9,98 persen, kemudian diikuti oleh industri kayu, barang dari kayu dan 
gabus dan barang anyaman dari bambu, rotan dan sejenisnya dan industri furnitur yaitu sebesar 6,90 persen dan 6,15 persen. Secara terperinci disajikan perkembangan industri di NTB sebagai berikut :

Berdasarkan di atas perkembangan industri NTB mengalami fluktuasi, terutama pada industri kecil dan menengah. Jumlah IKM yang awalnya berjumlah 87.279 unit usaha pada tahun 2014, turun menjadi 85.274 unit usaha di tahun 2016. Sedangkan IBS kurang mengalami perubahan yang sangat berarti, hanya mengalami peningkatan jumlahnya dari 137 unit usaha pada tahun 2014 menjadi 155 unit usaha tahun 2016. Secara umum komposisi industri di NTB 51,1\% merupakan industri makanan dan minuman, 25,9\% industri pengolahan tembakau dan 6,1\% merupakan industri kayu, barang dari kayu dan gabus dan barang anyaman dari bambu, rotan dan sejenisnya.

\section{Gambaran Tenaga Kerja Provinsi Nusa Tenggara Barat}

Jumlah penduduk yang merupakan angkatan kerja di NTB sebesar 2.464 .331 orang dimana sejumlah 2.367.310 orang diantaranya bekerja, pencari kerja (pengangguran) sebanyak 97.021 orang, sekolah 306.812 orang, mengurus rumah tangga 546.728 orang dan sisanya penerima pendapatan. Menurut sensus penduduk 2016 Tingkat Partisipasi Angkatan Kerja (TPAK) NTB menunjukkan adanya peningkatan. TPAK NTB meningkat dari 66,54 persen pada tahun 2015 menjadi 71,57 persen pada tahun 2016, dimana TPAK lakilaki lebih tinggi dibandingkan dengan perempuan, yaitu masing-masing $82,35 \%$ dan 51,35\%. Peningkatan TPAK menunjukkan semakin tingginya pasokan tenaga kerja (labour supply) yang tersedia untuk memproduksi barang dan jasa. Dari hasil Sakernas menunjukkan bahwa secara umum jumlah penduduk yang ikut aktif dalam kegiatan ekonomi mengalami peningkatan sebesar 5\% dibandingkan dengan tahun 2015.

\section{Gambaran Tingkat Upah Provinsi Nusa Tenggara Barat}

Upah minimum yang diterapkan oleh setiap kabupaten/kota di NTB memiliki nilai berbeda. Upah minimum harus didasarkan pada Kebutuhan Hidup Layak (KHL) setiap kabupaten atau kota. UMK mulai diberlakukan berdasarkan pada peraturan Menteri Tenaga Kerja (Menaker) No. 3 tahun 1997 yang sekarang diubah dalam keputusan Menteri Tenaga Kerja dan Transmigrasi No. 226 tahun 2000 yang menyatakan bahwa semua pekerja baik yang berstatus tetap maupun yang tidak tetap serta masih dalam masa percobaan harus dibayar layak berdasarkan UMR atau UMK. Besarnya UMK setiap tahun mengalami kenaikan dan terus mengikuti kebutuhan hidup layak yang ditentukan oleh masing-masing kabupaten/kota.

UMK tertinggi di NTB adalah Kabupaten Bima dan Kota Bima, sedangkan yang terendah adalah Kabupaten Lombok Tengah. Kabupaten Bima dan Kota Bima memiliki UMK yang tertinggi sebab kedua daerah tersebut memiliki beberapa pusat industri dan kawasan strategis yang cukup berkembang di bidang pertumbuhan ekonomi khususnya dengan fokus pengembangan sektor pariwisata, industri dan perikanan, sehingga adanya potensi yang sangat strategis dalam pengembangan wilayah tersebut tentu saja akan berpengaruh terhadap kebutuhan hidup layak yang sangat tinggi. Pergerakan upah minimum terus mengalami kenaikan setiap tahun. Pada tahun 2016 Kabupaten Bima dan Kota Bima memiliki UMK yang sama yaitu sebesar Rp. 1.650.000.

\section{Konsentrasi Spasial Industri Kecil Menengah di Nusa Tenggara Barat}

Konsentrasi spasial merupakan pengelompokkan setiap industri dan aktivitas ekonomi secara spasial, dimana industri tersebut berlokasi pada suatu wilayah tertentu. Pada penelitian ini konsentrasi spasial industri kecil menengah di Provinsi NTB dihitung dengan menggunakan Consentration Ratio (CR). Rasio konsentrasi secara luas digunakan dalam mengukur pangsa pasar dari nilai output empat industri terbesar pada sebuah kabupaten/kota dengan total nilai output industri yang ada di provinsi. Dari hasil perhitungan rasio konsentrasi dapat diperingkat kabupaten/kota mana yang menguasai pangsa pasar sebuah industri, sehingga dapat disimpulkan bahwa konsentrasi spasial industri berada pada daerah tersebut.

Berikut adalah hasil perhitungan rasio konsentrasi 8 kabupaten dan 2 kota di Provinsi NTB.

Tabel 1. Rasio Konsentrasi (CR4) Berdasarkan Nilai Output Industri Kecil Menegah di Provinsi Nusa Tenggara Barat Tahun 2014-2016 Dalam Persen

\begin{tabular}{|l|l|l|l|l|l|}
\hline \multirow{2}{*}{ No } & \multirow{2}{*}{ Kabupaten/Kota } & \multicolumn{3}{|c|}{ Tahun } & \multirow{2}{*}{ Rata-rata } \\
\cline { 3 - 5 } & & 2014 & 2015 & 2016 & \\
\hline 1 & Lombok Barat & 8,48 & 7,61 & 9,73 & 8,61 \\
\hline 2 & Lombok Tengah & 17,39 & 24,34 & 18,88 & 20,20 \\
\hline 3 & Lombok Timur & 6,47 & 6,41 & 9,24 & 7,37 \\
\hline 4 & Sumbawa & 2,43 & 2,28 & 2,61 & 2,44 \\
\hline 5 & Dompu & 0,22 & 0,27 & 0,44 & 0,31 \\
\hline 6 & Bima & 2,40 & 2,63 & 4,01 & 3,01 \\
\hline 7 & Sumbawa Barat & 1,10 & 1,17 & 5,59 & 2,62 \\
\hline 8 & Lombok Utara & 28,98 & 2,25 & 2,97 & 11,40 \\
\hline 9 & Mataram & 26,81 & 47,72 & 39,88 & 38,14 \\
\hline 10 & Kota Bima & 3,47 & 3,13 & 3,86 & 3,49 \\
\hline
\end{tabular}

Sumber : data sekunder diolah 
Nilai konsentrasi industri kecil menengah di Provinsi NTB pada tahun 2014-2016 berdasarkan nilai output industri wilayah menunjukkan bahwa Kota Mataram memiliki tingkat rasio konsentrasi rata-rata paling tinggi yaitu sebesar 38,14\%. Hasil tersebut menunjukkan bahwa IKM di Provinsi NTB terkonsentrasi secara spasial di Kota Mataram. Peringkat kedua ditempati oleh Kabupaten Lombok Tengah dengan tingkat rasio konsentrasi rata-rata sebesar 20,20\%. Peringkat ketiga yaitu Kabupaten Lombok Utara dengan nilai rasio konsentrasi rata-rata sebesar $11,40 \%$. Kondisi ini menunjukkan bahwa IKM di Provinsi NTB masih terkumpul di daerah pusat pemerintahan dan kegiatan ekonomi, dimana pada ketiga daerah tersebut memiliki berbagai infrastruktur yang mampu mendorong berkembangnya kawasan industri, baik industri besar maupun industri kecil di Provinsi NTB.

Hasil pengamatan juga menunjukkan bahwa kenyataannya konsentrasi IKM secara regional tidak mengalami pergeseran yang berarti selama periode penelitian. Perkembangan IKM selama periode 2014 hingga 2016 selalu terkonsentrasi di kabupaten/kota yang berada di Pulau Lombok, baik menurut unit usaha maupun nilai outputnya. Konsentrasi IKM berada di Kota Mataram, kedua terbesar adalah Kabupaten Lombok Tengah, ke tiga adalah Kabupaten Lombok Utara, ke empat adalah Kabupaten Lombok Barat, kelima adalah Kabupaten Lombok Timur. Beberapa kabupaten/kota di Pulau Lombok mendominasi pertumbuhan IKM dengan pangsa pasar yang relatif besar. Kabupaten/kota yang mendominasi tersebut adalah Kota Mataram dan Kabupaten Lombok Tengah. Kedua kabupaten/kota tersebut memiliki pangsa pasar antara 20\% hingga 38\%. Sedangkan kabupaten/kota di Pulau Sumbawa yang luas wilayahnya hampir $76 \%$ dari luas wilayah NTB memiliki pangsa pasar yang relatif kecil yaitu dibawah 5\%. Di Pulau Sumbawa, distribusi IKM terkonsentrasi di Kota Bima dengan rasio konsentrasi rata-rata sebesar 3,49\%. Sedangkan wilayah lainnya memiliki pangsa pasar kurang dari 3,49\%.

Dengan demikian distribusi IKM secara regional menunjukkan adanya pola konsentrasi IKM yang sangat tidak merata antar kabupaten/kota di Provinsi NTB, dimana terjadi konsentrasi IKM yang sangat tinggi di wilayah Kota Mataram, yaitu sekitar 38,14\%. Sedangkan wilayah Kabupaten Dompu merupakan wilayah yang memiliki nilai rasio konsentrasi paling rendah, yaitu sekitar $0,31 \%$.

\section{Konsentrasi Spasial Tenaga Kerja di Nusa Tenggara Barat}

Hasil menunjukkan kontribusi daerah dalam penyerapan tenaga kerja dari setiap kabupaten/kota tidak sama. Terdapat 6 kabupaten/kota yang memiliki peran lebih besar dari peran Provinsi NTB dalam penyerapan tenaga kerja atau nilai $\mathrm{CI}>1$. Kabupaten/kota yang memiliki nilai indeks konsentrasi rata-rata lebih dari satu (CI>1) yaitu Kabupaten Sumbawa dengan rata-rata CI sebesar 1,05, Kabupaten Lombok Utara 1,04, Kabupaten Lombok Tengah 1,03, Kota Bima 1,03, Kabupaten Bima 1,02 dan Kabupaten Lombok Barat 1,01. Jadi daerah tersebut merupakan basis dari penyerapan tenaga kerja yang potensial di Provinsi NTB. Selain itu, adanya kuantitas daerah yang memiliki indeks konsentrasi lebih dari satu di Provinsi NTB menandakan terjadinya pola konsentrasi tenaga kerja di kabupaten/kota tersebut yang sangat signifikan.

Sedangkan 4 daerah yang memiliki nilai indeks konsentrasi rata-rata kurang dari satu $(\mathrm{CI}<1)$, yaitu Kabupaten Sumbawa Barat dengan rata-rata CI sebesar 0,99, Kota Mataram 0,98, Kabupaten Lombok Timur 0,97 dan Kabupaten Dompu 0,87. Wilayah tersebut memiliki peran penyerapan tenaga kerja lebih kecil daripada wilayah lain di Provinsi NTB. Kabupaten/kota yang memiliki CI $<1$ juga memiliki industri yang beragam, namun penyerapan tenaga kerja tidak lebih besar dari kepadatan penduduk yang tinggi.

Selama periode pengamatan tahun 2014-2016 kabupaten/kota yang secara konsisten memiliki peran penyerapan tenaga kerja diatas peran Provinsi NTB adalah hanya Kabupaten Lombok Tengah saja dengan indeks konsentrasi rata-rata sebesar 1,03. Hal ini menunjukkan bahwa Kabupaten Lombok Tengah memberikan kontribusi yang cukup besar terhadap penyerapan tenaga kerja di Provinsi NTB.

Sedangkan kabupaten/kota lainnya tidak konsisten dalam penyerapan tenaga kerja walaupun ada beberapa kabupaten/kota yang memiliki indeks konsentrasi lebih dari satu tiap tahun analisis tersebut. Dari hasil pengamatan menunjukkan bahwa masih terdapat kabupaten/kota yang memiliki peran lebih kecil dari Provinsi NTB sehingga kurang memberikan kontribusi cukup besar dalam penyerapan tenaga kerja.

Kabupaten/kota yang unggul dalam indeks konsentrasi mempunyai industri kecil menengah yang mengembangkan potensi daerah. Sehingga ciri khas daerah mampu dikembangkan dan dilestarikan. Selain itu bahan baku lokal dapat dimanfaatkan dalam pembuatan produk industri tersebut. Sehingga, industri kecil menengah lokal dapat berperan dalam penciptaan lapangan kerja, yang pada akhirnya tujuan dalam penyerapan tenaga kerja tercapai. Produksi dan penyerapan tenaga kerja berperan penting terhadap pertumbuhan ekonomi regional dimasing-masing kabupaten/kota.

\section{Analisis Regresi Data Panel}

\section{a. Model Pooled Least Square (PLS)}

Berdasarkan tabel 4.8 diketahui bahwa slope tenaga kerja (TK) sebesar 1,363819 dengan p-value 0,0000, slope nilai upah (U) sebesar - 0.543034 dengan $p$-value 0,5217 dan slope nilai produktivitas (NP) 
sebesar 1,067799 dengan $p$-value 0,0000. Bila variabel independen benilai nol maka konsentrasi spasial IKM (CR4) sebesar -17,12923 dan error term sebesar 0,459680. Nilai R-squared 0,899663 atau 89,97\% dan Fstatistic sebesar 77,70928 dengan Prob(F-statistic) 0,000000. Model estimasi Pooled Least Square adalah sebagai berikut :

$\mathrm{CR}_{\text {it }}=-17,12923+1,363819 * \mathrm{TK}_{\mathrm{it}}-0,543034 * \mathrm{U}_{\mathrm{it}}+1,067799 * \mathrm{NP}_{\mathrm{it}}+\varepsilon_{\mathrm{it}}$

\section{b. Model Random Effect (REM)}

Berdasarkan tabel 4.8 diketahui bahwa slope tenaga kerja (TK) sebesar 1,364736 dengan p-value 0,0000, slope upah (U) sebesar -0,143521 dengan p-value 0,6967 dan slope nilai produktivitas (NP) sebesar 0,904272 dengan $p$-value 0,0000. Bila variabel independen benilai nol maka konsentrasi spasial IKM (CR4) sebesar -21,29428 dan error term sebesar 0,184333. Nilai R-squared 0,900570 atau 90,06\% dan F-statistic sebesar 78,49696 dengan Prob(F-statistic) 0,000000. Model estimasi Random Effect Model adalah sebagai berikut :

$\mathrm{CR}_{\mathrm{it}}=-21,29428+1,364736 * \mathrm{TK}_{\mathrm{it}}-0,143521 * \mathrm{U}_{\mathrm{it}}+0,904272 * \mathrm{NP}_{\mathrm{it}}+\varepsilon_{\mathrm{it}}$

\section{Pemilihan Model Estimasi Regresi Data Panel}

\section{a. Uji Chow/Likelihood Test Ratio}

Uji Chow/Likelihood Ratio digunakan untuk memilih model regresi data panel yang paling baik antara Pooled Least Square dan Fixed Effect Model. Aplikasi yang digunakan untuk uji Chow menggunakan program E-views 9. Hasil pengolahan Output regresi Chow test menunjukkan nilai probabilitas F-statistik = $0,0000 \leq 0,05$, maka $\mathrm{H}_{0}$ ditolak dan $\mathrm{H}_{\mathrm{a}}$ diterima sehingga model mengikuti Fixed Effect Model.

\section{b. Uji Hausman}

Output regresi Hausman test menunjukkan nilai probabilitas Chi-square statistik $=0,3420 \geq 0,05$, maka $\mathrm{H}_{0}$ diterima dan $\mathrm{H}_{\mathrm{a}}$ ditolak sehingga model mengikuti Random Effect Model.

\section{c. Uji Lagrange Multiplier (LM)}

Output regresi LM test menunjukkan nilai probabilitas B-P $=0,0000 \leq 0,05$, maka $\mathrm{H}_{0}$ ditolak dan $\mathrm{H}_{\mathrm{a}}$ diterima sehingga model mengikuti Random Effect Model.

Berdasarkan hasil estimasi data panel untuk memilih model yang terbaik dengan uji Chow, uji Hausman dan uji Lagrange Multiplier, maka terpilih Random Effect Model adalah model yang paling tepat untuk menganalisis data dalam penelitian ini.

Dari hasil estimasi diatas, maka dapat dibentuk persamaan regresi data panel sebagai berikut :

$\mathrm{CR} 4_{\text {it }}=-21,29428+1,364736 * \mathrm{TK}_{\mathrm{it}}-0,143521 * \mathrm{U}_{\mathrm{it}}+0,904272 * \mathrm{NP}_{\mathrm{it}}+\varepsilon_{\text {it }}$

Persamaan model regresi tersebut dapat dijelaskan secara terperinci sebagai berikut :

1. $\beta_{0}=-21,29428$ merupakan nilai konstanta. Nilai tersebut menunjukkan bahwa tingkat konsentrasi spasial akan mengalami penurunan sebesar 21,29428 persen apabila variabel tenaga kerja, upah dan nilai produktivitas konstan.

2. $\beta_{1}=1,364736$ merupakan koefisien regresi variabel tenaga kerja. Nilai tersebut menunjukkan pengaruh tenaga kerja terhadap konsentrasi spasial sebesar 1,364736 artinya, apabila terjadi kenaikan tenaga kerja sebesar satu persen maka akan meningkatkan konsentrasi spasial sebesar 1,364736 persen dengan asumsi variabel lain konstan.

3. $\beta_{2}=-0,143521$ merupakan koefisien regresi variabel upah. Nilai tersebut menunjukkan pengaruh upah terhadap konsentrasi spasial sebesar -0,143521 artinya, apabila terjadi kenaikan upah sebesar satu persen maka konsentrasi spasial akan mengalami penurunan sebesar 0,143521 persen dengan asumsi variabel lain konstan.

4. $\beta_{3}=0,904272$ merupakan koefisien regresi variabel nilai produktivitas. Nilai tersebut menunjukkan pengaruh nilai produktivitas terhadap konsentrasi spasial sebesar 0,904272 artinya, apabila terjadi kenaikan nilai produktivitas sebesar satu persen maka akan meningkatkan konsentrasi spasial sebesar 0,904272 persen dengan asumsi variabel lain konstan.

\section{Uji Kriteria Statistik}

Dari persamaan regresi data panel, selanjutnya diadakan pengujian statistik, diantaranya ialah: A) Uji t (uji pengaruh secara parsial), B) Uji F (uji pengaruh secara simultan), C) Uji $\mathrm{R}^{2}$ (koefisien determinasi).

\section{a. Uji t (Uji Pengaruh Secara Parsial)}

Dari hasil estimasi diatas menunjukkan bahwa secara parsial variabel bebas yang mempunyai pengaruh signifikan terhadap variabel terikat (konsentrasi spasial) yaitu tenaga kerja (TK) dan nilai produktivitas (NP), sedangkan upah (U) tidak berpengaruh signifikan.

Variabel tenaga kerja (TK) mempunyai nilai t-statistik 6,769888 > t-tabel 2,056 dan nilai probabilitas t-statistik $0,0000 \leq 0,05$ maka $\mathrm{H}_{0}$ ditolak dan $\mathrm{H}_{\mathrm{a}}$ diterima, artinya secara parsial tenaga kerja berpengaruh signifikan terhadap konsentrasi spasial IKM di Provinsi NTB. 
Variabel upah (U) mempunyai nilai t-statistik $-0,394115<\mathrm{t}$-tabel 2,056 dan nilai probabilitas tstatistik 0,6967 $\geq 0,05$ maka $\mathrm{H}_{0}$ diterima dan $\mathrm{H}_{\mathrm{a}}$ ditolak, artinya secara parsial upah tidak berpengaruh signifikan terhadap konsentrasi spasial IKM di Provinsi NTB.

Variabel nilai produktivitas (NP) mempunyai nilai t-statistik 15,02499 > t-tabel 2,056 dan nilai probabilitas t-statistik $0,0000 \leq 0,05$ maka $\mathrm{H}_{0}$ ditolak dan $\mathrm{H}_{\mathrm{a}}$ diterima, artinya secara parsial nilai produktivitas berpengaruh signifikan terhadap konsentrasi spasial IKM di Provinsi NTB.

\section{b. Uji F (Uji Pengaruh Secara Simultan)}

Dari hasil estimasi dengan mengambil $\alpha$ sebesar 5\% maka dari tabel distribusi $\mathrm{F}$ diperoleh nilai $\mathrm{F}$ tabel untuk $\mathrm{F}_{0,05}$ (3.26) adalah 2,99. Berdasarkan hasil perhitungan melalui program E-views 9 (lampiran 9) diperoleh nilai F-statistik sebesar 78,49696 sehingga dapat dibandingkan bahwa F-statistik > F-tabel. Ini diperkuat dengan nilai probabilitas F-statistik $=0,000000 \leq$ nilai probabilitas $\alpha=0,05$ maka $\mathrm{H}_{0}$ ditolak dan $\mathrm{H}_{\mathrm{a}}$ diterima, artinya semua variabel independen mampu menjelaskan variabel dependen atau secara bersamasama variabel independen tenaga kerja (TK), upah (U) dan nilai produktivitas (NP) berpengaruh signifikan terhadap variabel dependen CR4 atau tingkat konsentrasi spasial IKM di Provinsi NTB.

\section{c. Uji $\mathbf{R}^{2}$ (Koefisien Determinasi)}

Hasil perhitungan dengan program E-views 9 (lampiran 9) menunjukkan nilai R-squared $=0,900570$, artinya total variasi konsentrasi spasial (CR4) IKM kabupaten/kota di Provinsi NTB mampu dijelaskan oleh variabel-variabel independen tenaga kerja (TK), upah (U) dan nilai produktivitas (NP) sebesar 90,06\%, sedangkan sisanya 9,94\% dijelaskan oleh variabel-variabel lain diluar model.

\section{Konsentrasi Spasial Industri Kecil Menegah dan Tenaga Kerja}

Adanya kabupaten/kota yang memiliki pangsa yang besar dibandingkan wilayah lain menunjukkan bahwa kabupaten/kota tersebut memiliki keunggulan berupa daya saing pada industrinya. Kota Mataram dan Kabupaten Lombok Tengah memiliki nilai konsentrasi industri yang sangat tinggi, fenomena ini menunjukkan bahwa industri kecil menengah di Provinsi NTB terkonsentrasi di daerah pusat pemerintahan dan kawasan pusat kegiatan ekonomi. Menurut Montgomery (dalam Erlangga, 2004) munculnya konsentrasi spasial dari aktivitas ekonomi di kawasan perkotaan disebabkan karena penghematan akibat lokasi yang berdekatan (economies proximity) yang diasosiasikan dengan klaster spasial dari perusahaan, para pekerja dan konsumen. Kota Mataram sebagai daerah core, sedangkan Kabupaten Lombok Tengah sebagai daerah periphery memiliki infrastruktur dan fasilitas yang cukup baik. Menurut Tarigan (2005: 145) suatu industri akan terkonsentrasi pada wilayah yang memiliki fasilitas pendukung yang mampu melayani industri-industri baik pada klaster maupun kota, ketersediaan fasilitas tersebut akan memberikan kemudahan dalam mendistribusikan barang atau jasa hasil produksinya. Kota Mataram memiliki dukungan infrastruktur dan fasilitas berupa sarana transportasi, jalan raya, perumahan, sarana publik, pelayanan jasa komersial serta sarana informasi dan telekomunikasi.

Konsentrasi spasial bisa terjadi akibat adanya aglomerasi yang disebabkan oleh upaya mengurangi biaya transportasi dengan berlokasi di sekitar local demand yang besar serta upaya untuk memperoleh akses pasar yang luas (Krugman, 1991). Kota Mataram sebagai daerah yang memiliki kepadatan penduduk tertinggi yaitu sebesar $7.345 \mathrm{jiwa} / \mathrm{km}^{2}$, diikuti oleh Kabupaten Lombok Tengah sebesar $763 \mathrm{jiwa} / \mathrm{km}^{2}$. Jumlah penduduk yang besar merupakan pangsa pasar potensial yang mendukung industri dan merupakan natural advantages wilayah yang berperan penting dalam proses aglomerasi, oleh sebab itu banyak industri kecil menengah yang terkonsentrasi pada kedua daerah tersebut. Hal ini didukung oleh teori lokasi yaitu Market Area Theory yang dipelopori oleh August Losch, menurutnya faktor permintaan lebih penting artinya dalam persoalan pemilihan lokasi. Losch berpendapat bahwa pemilihan lokasi industri akan lebih banyak ditentukan oleh besarnya ongkos angkut untuk hasil produksi dan tingkat persaingan sesama produsen di pasar (spatial competition).

Para tokoh klasik beranggapan bahwa terjadinya pola konsentrasi industri yang berbeda dari daerah satu dengan daerah lain itu karena adanya orientasi-orientasi perusahaaan dalam menentukan lokasi industri yaitu karena adanya penghematan aglomerasi yang menarik aktivitas ekonomi ke daerah perkotaan (sentripetal) dan kekuatan sentrifugal. Kabupaten/kota yang paling tinggi peringkat rasio konsentrasinya berlokasi di sekitar pusat perekonomian dan di sekitar daerah bahan baku. Konsentrasi IKM memiliki hubungan dengan intensitas pertanian di suatu daerah. IKM yang memproduksi makanan dan minuman di daerah pedesaan banyak menggunakan komoditas pertanian sebagai bahan baku utamanya. Demikian pula IKM yang memproduksi barang kerajinan tangan seperti ukir, rotan dan gerabah banyak menggunakan bahan baku lokal.

Teori klasik tersebut didukung oleh fenomena yang terjadi di Provinsi NTB dimana Kota Mataram selain sebagai pusat pemerintahan juga menjadi pusat perekonomian di Provinsi NTB. Sedangkan Kabupaten Lombok Tengah mempunyai luas wilayah yang sebagian besar digunakan sebagai lahan pertanian dan 
perkebunan. Hasil dari sektor pertanian ini yang nantinya dijadikan sebagai bahan utama industri kecil menengah. Oleh karena itu, adanya faktor pendukung tersebut mampu mendorong munculnya ekonomi rakyat yang ditandai dengan bertambahnya jumlah IKM yang ada di sekitar kawasan ekonomi tersebut.

Kontribusi masing-masing wilayah dalam penyerapan tenaga kerja tidak sama. Hasil analisis menunjukkan bahwa kabupaten/kota yang memiliki peran lebih besar daripada peran Provinsi NTB dalam penyerapan tenaga kerja adalah Kabupaten Sumbawa, Kabupaten Lombok Utara, Kabupaten Lombok Tengah, Kota Bima, Kabupaten Bima dan Kabupaten Lombok Barat. Hal ini mengindikasikan bahwa penyerapan tenaga kerja di setiap kabupaten/kota tersebut sangat baik karena mampu menyerap tenaga kerja tidak hanya dari wilayahnya tetapi mampu menyerap tenaga kerja dari luar wilayahnya sendiri. Daerahdaerah tersebut memiliki indeks konsentrasi lebih dari satu yang menandakan terjadinya pola konsentrasi tenaga kerja di kabupaten/kota tersebut. Kondisi ini menunjukkan adanya ketidakmerataan dalam distribusi tenaga kerja pada tingkat kabupaten/kota di Provinsi NTB. Di beberapa kabupaten/kota mengalami penyerapan tenaga kerja yang tinggi, sementara sebagian yang lain justru mengalami penyerapan tenaga kerja yang rendah.

Besarnya angka peranan Kabupaten Sumbawa dalam penyerapan tenaga kerja membuktikan bahwa daerah ini merupakan daerah yang tepat untuk dikembangkan dalam upaya perluasan kesempatan kerja. Dengan potensinya dalam menyerap tenaga kerja, menunjukkan kabupaten ini memiliki kemampuan untuk mengurangi pengangguran jika dikelola dengan baik oleh pemerintah daerah. Selain itu, jika sektor-sektor ekonomi potensial di daerah tersebut mampu dikembangkan secara menyeluruh, maka kesempatan kerja yang tercipta pun semakin banyak sehingga penyerapan tenaga kerja di Kabupaten Sumbawa akan mengalami peningkatatan.

Menurut Marshall (dalam Kacung, 2005), ketersediaan tenaga kerja spesialis akan menguntungkan suatu perusahaan. Adanya tenaga kerja yang terkonsentrasi merupakan bagian dari faktor yang merupakan determinan dari keunggulan suatu wilayah. Namun, perlu diketahui bahwa tenaga kerja yang berlebihan kepada perluasan industri modern tidak akan dapat mengatasi masalah ketenagakerjaan, dikarenakan industri modern senantiasa bercirikan padat modal sehingga daya serap terhadap tenaga kerja yang ada menjadi terbatas. Jangankan untuk menyerap tenaga kerja yang ada, bahkan untuk mempertahankan proporsi penyerapan tenaga kerja itu saja sudah sangat sulit (Williamson, 2000: 11). Oleh karena itu perlu adanya peningkatan produktivitas sumberdaya manusia sehingga kesejahteraan pekerja dapat terwujud karena tingginya produktivitas berarti keuntungan akan tinggi dan upah juga lebih tinggi.

\section{Pengaruh Tenaga Kerja Terhadap Konsentrasi Spasial}

Secara parsial variabel tenaga kerja mempunyai pengaruh positif dan signifikan terhadap konsentrasi spasial, artinya ketika jumlah tenaga kerja meningkat maka konsentrasi spasial IKM di Provinsi NTB juga akan mengalami peningkatan. Besar nilai koefisien regresi dari variabel tenaga kerja adalah 1,364736 berarti setiap peningkatan variabel tenaga kerja sebesar satu persen maka akan meningkatkan variabel konsentrasi spasial sebesar 1,364736 persen dengan asumsi variabel lainnya konstan atau cateris paribus. Hal ini berarti hipotesis yang menyatakan bahwa variabel tenaga kerja berpengaruh signifikan terhadap konsentrasi spasial terbukti. Hasil penelitian ini didukung oleh penelitian terdahulu yang dilakukan oleh Arifin (2006) yang berjudul "Konsentrasi Spasial Industri Manufaktur Berbasis Perikanan di Jawa Timur: Studi Kasus Industri Besar dan Sedang" memperoleh hasil bahwa tenaga kerja berpengaruh positif dan signifikan terhadap konsentrasi spasial industri manufaktur dengan besarnya koefisien 0,135949 .

Para pemikir klasik berpendapat bahwa konsentrasi spasial didorong oleh ketersediaan tenaga kerja yang terspesialisasi dimana berkumpulnya perusahaan pada suatu lokasi akan mendorong berkumpulnya tenaga kerja, sehingga menguntungkan perusahaan dan tenaga kerja. Adanya spesialisasi tenaga kerja pada suatu daerah akan menciptakan aglomerasi industri di daerah tersebut. Aglomerasi dapat disimpulkan berkaitan dengan konsentrasi dari beberapa fasilitas pendukung yang melayani industri-industri, dimana salah satu fasilitas tersebut adalah ketersediaan tenaga kerja terampil yang akan berpengaruh terhadap konsentrasi spasial (Tarigan, 2005: 145). Selain itu, industri kecil menengah juga merupakan sektor yang menggunakan teknologi padat karya yang dapat memperbesar lapangan kerja dan kesempatan usaha, sehingga mampu menyerap tenaga kerja yang cukup banyak dibandingkan dengan industri berskala besar.

\section{Pengaruh Upah Terhadap Konsentrasi Spasial}

Variabel upah mempunyai pengaruh negatif dan tidak signifikan terhadap konsentrasi spasial, artinya ketika tingkat upah meningkat belum tentu konsentrasi spasial IKM di Provinsi NTB akan mengalami penurunan. Besar nilai koefisien regresi dari variabel upah adalah $-0,143521$ berarti setiap peningkatan variabel upah sebesar satu persen maka akan menyebabkan penurunan variabel konsentrasi spasial sebesar 0,143521 persen dengan asumsi variabel lainnya konstan atau cateris paribus. Hal ini berarti hipotesis yang 
menyatakan bahwa variabel upah berpengaruh signifikan terhadap konsentrasi spasial tidak terbukti. Hasil penelitian ini didukung oleh penelitian terdahulu yang dilakukan oleh Saputra (2015) yang berjudul "Analisis Spesialisasi dan Konsentrasi Spasial Industri Kecil Menengah di Jawa Timur" memperoleh hasil bahwa tingkat upah berpengaruh negatif dan tidak signifikan terhadap konsentrasi spasial IKM dengan besarnya koefisien $-0,217185$.

\section{Pengaruh Nilai Produktivitas Terhadap Konsentrasi Spasial}

Variabel nilai produktivitas mempunyai pengaruh positif dan signifikan terhadap konsentrasi spasial, artinya ketika nilai produktivitas meningkat maka konsentrasi spasial IKM di Provinsi NTB juga akan mengalami peningkatan. Besar nilai koefisien regresi dari variabel nilai produktivitas adalah 0,904272 berarti setiap peningkatan variabel nilai produktivitas sebesar satu persen maka akan meningkatkan variabel konsentrasi spasial sebesar 0,904272 persen dengan asumsi variabel lainnya konstan atau cateris paribus. Hal ini berarti hipotesis yang menyatakan bahwa variabel nilai produktivitas berpengaruh signifikan terhadap konsentrasi spasial terbukti. Hasil penelitian ini didukung oleh penelitian terdahulu yang dilakukan oleh Sulastri (2013) yang berjudul "Konsentrasi Spasial Industri: Kajian Empirik di Indonesia" memperoleh hasil bahwa produktivitas berpengaruh positif dan signifikan terhadap konsentrasi spasial industri dengan besarnya koefisien 0,256 .

\section{PENUTUP}

\section{Simpulan}

1. Berdasarkan rasio konsentrasi (CR4) menemukan bahwa pola konsentrasi industri kecil menengah di Provinsi NTB pada periode pengamatan 2014-2016 tidak merata secara geografis.

2. Dari hasil indeks konsentrasi (CI), distribusi tenaga kerja di Provinsi NTB juga menunjukkan kondisi yang tidak merata dan cenderung terkonsentrasi Kabupaten Sumbawa, Kabupaten Lombok Utara, Kabupaten Lombok Tengah, Kota Bima, Kabupaten Bima dan Kabupaten Lombok Barat.

3. Berdasarkan hasil estimasi pengaruh variabel tenaga kerja, upah dan nilai produktivitas terhadap konsentrasi spasial berdasarkan perhitungan pada nilai rasio konsentrasi terhadap nilai output industri kecil menengah di Provinsi NTB tahun 2014-2016 bahwa variabel tenaga dan nilai produktivitas berpengaruh positif dan signifikan terhadap konsentrasi spasial IKM.

\section{Saran}

1. Bagi penentu kebijakan dalam hal ini adalah Pemerintah Provinsi NTB diharapkan menaruh perhatian yang lebih besar pada pembangunan prasarana dan infrastruktur yang mempunyai peranan cukup tinggi dalam menciptakan pertumbuhan ekonomi antar daerah. Aksesibilitas yang memadai baik ke pasar maupun ke faktor industri.

2. Bagi peneliti berikutnya, disarankan perlu melakukan pengkajian dan analisis yang lebih rinci dan mendalam tentang konsentrasi spasial. Diperlukan juga bagi peneliti selanjutnya untuk menambahkan jumlah data yang akan dianalisis agar memperoleh hasil penelitian yang lebih optimal, serta meneliti variabel lainnya yang dapat mempengaruhi tingkat konsentrasi spasial industri kecil menengah yang berada diluar model penelitian ini seperti investasi, bahan baku dan tingkat persaingan.

\section{DAFTAR PUSTAKA}

Aiginger, K. and Hansberg, E. (2003). Specialization Versus Concentration: A Notes of Theory and Evidence. SIEPR Working Paper.

Arsyad, L. (1999). Ekonomi Pembangunan. Yogyakarta: Bagian Penerbitan STIE YKPN.

Arsyad, L. dan Kusuma, S.E. (2014). Ekonomika Industri: Pendekatan Struktur, Perilaku dan Kinerja. Yogyakarta: UPP STIM YKPN.

Disperindag. (2002). Rencana Induk Pengembangan Industri Kecil Menengah 2002-2004. Jakarta: Departemen Perindustrian dan Perdagangan RI.

Kuncoro, Mudrajad. (2002). Analisis Spasial dan Regional: Studi Aglomerasi dan Kluster Industri Indonesia. Yogyakarta: UPP AMP YKPN.

Marijan, Kacung. (2005). Mengembangkan Industri Kecil Menengah Melalui Pendekatan Kluster. Insan Vol. 3 No. 7.

Undang-Undang . (203). Undang-Undang No. 13 Tahun 2003 Tentang Ketenagakerjaan. Jakarta 